\title{
ANALISIS PERBANDINGAN PUTUSAN PEMIDANAAN TERHADAP PELAKU TINDAK PIDANA PERDAGANGAN ORANG (T.P.P.O) (STUDI PUTUSAN NOMOR 632 K/PID.SUS/2016 DAN PUTUSAN NOMOR 1447K/ PID.SUS/ 2016)
}

\author{
Saras Sulistyawati
}

\begin{abstract}
ABSTRAK
Human Trafficking is an act of recruitment, shelter, sending, transferring, or accepting someone with the threat of violence, using violence, kidnapping, confinement, counterfeiting, fraud, abuse of power or vulnerable positions, debt bondage or paying or benefits, so obtain approval from the person who holds control over the other person, whether carried out within the state or between countries, for the purpose of exploitation or to result in exploitation (Law Number 21 of 2007 concerning the Eradication of Crimes in Trafficking in Persons).

This study aims to analyze aspects of judges' consideration of the criminal termination of perpetrators of trafficking in persons in Decision Number 632.K / PID.SUS / 2016 and Decisions Number 1447.K / PID.SUS / 2016, covering juridical, philosophical, and sociological aspects. Juridical aspects are based on the existing legal umbrella and judge as the applicator, sociological aspects, namely the application of the law concerning the values of society in order to create legal justice, and philosophical aspects that are based on the value of truth and justice.

This research is a type of normative juridical research that focuses on studying the application of positive legal norms or norms.

The problem in this study regarding the basis of the judge's consideration in imposing criminal sanctions against perpetrators of trafficking in persons and the comparison of judges' considerations related to criminal imposition of perpetrators of human trafficking in decisions No. 632.K / PID.SUS / 2016 and Decisions Number 1447.K / PID.SUS / 2016.

From the results of this study indicate that, the application of the law where the judge as the applicator is in accordance with the values of the law, and the community, but still very minimal or the need for more policies on victims of trafficking, namely the right to restitution (restoration of the rights of victims from trafficking).
\end{abstract}

Keywords: human trafficking, restitution, human trafficking, juridical, philosophical, sociological aspects. 


\section{PENDAHULUAN}

Tindak Pidana Perdagangan Orang (TPPO) merupakan tindak pidana yang dianggap baru dalam sistem hukum Indonesia, sekalipun bentuk perbuatan sudah sejak lama. Hal ini dikarenakan Undang Undang Pemberantasan Tindak Pidana Perdagangan Orang baru muncul dan disahkan oleh Pemerintah yaitu melalui Undang Undang Nomor 21 Tahun 2007 tentang Pemberantasan Tindak Pidana Perdagangan Orang, dan diundangkan pada tanggal 19 April 2007 dalam Lembaran Negara Tahun 2007 Nomor 58. ${ }^{1}$

Pengertian perdagangan orang diatur di dalam Pasal 1 Angka 1 Undang - Undang Nomor 21 Tahun 2007 Tentang Pemberantasan Tindak Pidana Perdagangan Orang yang berbunyi : "Perdagangan Orang adalah tindakan perekrutan, penampungan, pengiriman, pemindahan, atau penerimaan seseorang dengan ancaman kekerasan, penggunaan kekerasam, penculikan, penyekapan, pemalsuan, penipuan, penyalahgunaan kekuasaan atau posisi rentan, penjeratan utang atau memberi bayaran atau manfaat, sehingga memperoleh persetujuan dari orang yang yang memegang kendali atas orang lain tersebut, baik yang dilakukan di dalam negara maupun

${ }^{1}$ Henny Nuraeny, Tindak Pidana Perdagangan Orang Dalam Perspektif Hak Asasi Manusia, Rajawali Pers, Jakarta, 2016, hlm. 87. antar negara, untuk tujuan eksploitasi atau mengakibatkan orang tereksploitasi.",2

Pelaku perdagangan orang (trafficker) dalam melakukan kegiatannya dengan cara perekrutan, pengangkutan, pemindahan, penyembunyian, atau penerimaan orang, dengan cara menjebak, menjerumuskan, atau memanfaatkan orang tersebut dalam praktik eksploitasi dengan segala bentuknya termasuk kekerasan dan atau ancaman kekerasan, penculikan, pemalsuan, penipuan, penyalahgunaan kekuasaan atau posisi rentan, dengan cara memberi bayaran atau manfaat, sehingga memperoleh persetujuan dari orang yang memegang kendali atas korban. Korban akhirnya tidak mampu menolak suatu pekerjaan yang secara melawan hukum diperintahkan oleh orang lain (trafficker), walaupun korban tidak menghendakinya. $^{3}$

Kelompok yang paling banyak menjadi korban adalah perempuan dan anak. Umumnya menjadi komoditas pelacuran atau eksploitasi lainnya seperti kerja paksa atau pelayanan paksa, seperti pekerja domestik rumah tangga (pembantu rumah tangga) atau buruh kasar, pengantin pesanan, sampai pada kejahatan yang berbahaya bagi tubuh dan seperti transpalansi organ tubuh. Pola ini umumnya dilakukan

\footnotetext{
${ }^{2}$ Undang - Undang Nomor 21 Tahun 2007 tentang Pemberantasan Tindak Pidana Perdagangan Orang.

${ }^{3}$ Loc.Cit. hlm. 115.
} 
trafficker melalui cara, rencana, atau pola lainnya yang bersifat mengelabuhi, agar seseorang (korban/ atau calon korban) merasa yakin bahwa apabila tidak dapat melakukan pekerjaan tertentu, maka korban akan menanggung akibatnya, baik secara fisik maupun psikis.

Kejahatan (perdagangan orang) atau human trafficking itu sendiri terjadi karena tidak adanya penghormatan terhadap martabat kemanusiaan. Dimana manusia dipandang sebagai barang yang bisa ditentukan harganya tanpa persetujuannya, dibawa, dikumpulkan, dikurung, dan ditempatkan tanpa mempertimbangkan kebutuhannya sebagai manusia. ${ }^{4}$

Pidana terhadap pelaku tindak pidana perdagangan orang masih dianggap tidak memberikan efek jera dan pecegahan bagi pelaku maupun masyarakat untuk tidak melakukan hal tersebut. Terlebih lagi hal yang memberatkan yaitu pidana terhadap anak (seksual). Sehingga putusan pidana oleh hakim harus mampu memberikan efek jera bagi pelaku.

Hakim diberi wewenang oleh undang - undang untuk menerima, memeriksa serta memutus suatu perkara pidana, oleh karena itu hakim dalam menangani suatu perkara harus dapat berbuat adil,

${ }^{4}$ Candra Muzaffar dkk, Human's wrong: Rekor Buruk Dominasi Barat atas HAM, Pilar Media, Yogyakarta, 2007 hlm. 401. sebagai seorang hakim, dalam memberikan putusan kemungkinan dipengaruhi oleh hal yang ada pada dirinya dan sekitarnya karena pengaruh faktor agama, kebudayaan, pendidikan, nilai, norma dan sebagainya sehingga dapat dimungkinkan adanya perbedaan cara pandang sehingga mempengaruhi pertimbangan dalam memberikan putusan. ${ }^{5}$

Hakim memiliki kebebasan mandiri dalam menjatuhkan sanksi pidana penjara terhadap anak yang melakukan perbuatan melawan hukum. Kebebasan tersebut adalah mutlak dan tidak ada suatu pihak manapun yang dapat mengintervensi dalam menjatuhkan putusan. Hal ini bertujuan untuk menjamin agar putusan pengadilan benar - benar obyektif.

Kebebasan hakim dalam menjatuhkan pidana penjara juga harus berpedoman terhadap batasan maksimum dan juga minimum serta kebebasan yang dimiliki harus senantiasa berdasarkan atas rasa keadilan baik terhadap terdakwa, korban serta masyarakat luas. Selain itu putusan pengadilan oleh hakim harus dapat dipertanggungjawabkan terhadap Tuhan Yang Maha Esa. ${ }^{6}$

\footnotetext{
${ }^{5}$ Oemar Seno Aji, Hukum Hakim Pidana, Bumi Aksara, Jakarta, 1997. Hlm. 12.

${ }^{6}$ Rara Kristi Aditya Mutiaramadani, "Dasar Pertimbangan Hakim Dalam Menjatuhkan Sanksi Pidana Penjara Terhadap Anak Sebagai Pelaku Tindak Pidana Pencurian Dengan Teori Pemidanaan (Studi di Pengadilan Negeri Mojokerto)", Fakultas Hukum, Universitas Brawijaya, 2014.
} 
Ada beberapa faktor yang mempengaruhi hakim dalam membuat putusannya, dibagi menjadi faktor subjektif dan objektif. Faktor subjektif meliputi :

1. Sikap perilaku apriori yakni adanya sikap hakim yang sejak semula sudah menganggap bahwa terdakwa yang diperiksa dan diadili adalah orang yang memang bersalah dan harus dipidana.

2. Sikap perilaku emosional yakni putusan pengadilan akan dipengaruhi oleh perangai hakim. Hakim yang mempunyai perangai mudah tersinggung akan berbeda dengan perangai hakim yang tidak mudah tersinggung.

3. Sikap arogance power yakni sikap lain yang yang mempengaruhi suatu putusan adalah kecongkakan kekuasaan, disini hakim merasa dirinya berkuasa dan pintar melebihi orang lain (jaksa, pembela, ataupun terdakwa).

4. Moral yakni moral seorang hakim karena bagaimanapun juga pribadi seorang hakim diliputi oleh tingkah laku yang didasari oleh moral pribadi hakim tersebut dalam memeriksa serta memutus perkara.

Faktor objektif meliputi :

1. Latar belakang budaya yaitu kebudayaan, agama, pendidikan seseorang tentu ikut mempengaruhi putusan hakim. Meskipun latar belakang hidup budaya tidak bersifat determinis, tetapi faktor ini setidaknya ikut mempengaruhi hakim dalam mengambil suatu keputusan.

2. Profesionalisme yaitu kecerdasan serta profesionalisme seorang hakim ikut mempengaruhi putusannya. Perbedaan suatu putusan sering dipengaruhi oleh profesionalisme hakim tersebut. $^{7}$

\section{Perumusan Masalah}

Dari latar belakang tersebut di atas, maka dapat dirumuskan bahwa rumusan masalah dalam penelitian ini adalah sebagai berikut :

1) Bagaimanakah pertimbangan hakim terkait penjatuhan sanksi pidana terhadap pelaku tindak pidana perdagangan orang ?

2) Bagaimanakah perbandingan pertimbangan hakim terkait penjatuhan sanksi pidana terhadap pelaku tindak pidana perdagangan orang dalam Putusan Nomor 632K/ PID.SUS/2016 dan Putusan Nomor 1447K/ PID.SUS/2016 ?

\section{Tujuan dan Manfaat Penulisan}

Salah satu teori atau pendapat menyatakan bahwa tujuan pidana pada dasarnya untuk

\footnotetext{
${ }^{7}$ Yahya Harahap, sebagaimana dikutip M. Syamsudin, 2012, Konstruksi Baru Budaya Hukum Hakim Berbasis Hukum Progresif, Kencana, Jakarta,. Hlm. 93.
} 
mengubah atau mempengaruhi perilaku terpidana. Berbagai istilah digunakan untuk menyatakannya yaitu : rehabilitasi, reformasi, treatment of offenders, reedukasi, readaptasi sosial, resosialisasi, pemasyarakatan. Teori tersebut secara singkat disebut dengan teori "mempengaruhi perilaku”, "teori mendidik", atau "teori memperkuat kembali nilai nilai sosial masyarakat”.

Berikut beberapa pendapat para sarjana :

Hulsman :

- Hakikat pidana adalah "menyerukan untuk tertib” (tot de orde roepen);

- Pada hakikatnya pidana mempunyai dua tujuan yaitu mempengaruhi tingkah laku (gedrags beinvloeding) dan penyelesaian konflik (conflictoplossing).

G.P. Hoefnagels yang menyatakan $:^{9}$

- Pemberian sanksi atau pidana bertujuan agar orang berorientasi atau menyesuaikan diri dengan norma atau UU.

- Tujuan pidana untuk penyelesaian konflik dan mempengaruhi para pelanggar dan orang - orang lain

${ }^{8}$ L.H.C Hulsman, De strafrechtelijke sanctie en zijin maat, in wijsgerig Perspectief, 8 e jrg, no. 4 1968, hal. 219

${ }^{9}$ G.P. Hoefnagels, The Other Side Of Criminology, Kluwer-Deventer, Holand, 1969, h.138 ke arah perbuatan yang sesuai dengan hukum.

Menurut Andenaes, ada tiga bentuk pengaruh dari "general prevention": ${ }^{10}$

- Pengaruh pencegahan (deterrent effect);

- Pengaruh untuk memperkuat larangan - larangan moral (strengthen moral inhibitions ( $a$ moralizing effect).

- Pengaruh untuk mendorong kebiasaan perbuatan patuh pada hukum. (stimulate habitual lawabiding conduct).

Penelitian ini bertujuan untuk memecahkan permasalahan dan mencari jawaban dari permasalahan yang hendak diteliti. Tujuan dari penelitian ini adalah :

1. Untuk menjelaskan pertimbangan hakim terkait penjatuhan sanksi pidana terhadap pelaku tindak pidana perdagangan orang.

2. Untuk menjelaskan perbandingan pertimbangan hakim terkait penjatuhan sanksi pidana terhadap pelaku tindak pidana perdagangan orang dalam Putusan Nomor 632 K/ PID. SUS 2016 dan Putusan Nomor 1447 K/ PID. SUS/ 2016.

\footnotetext{
${ }^{10}$ Johannes Andenaes, Punishment and Deterrence, Ann Arbor The University Of Michigan Press, 1974, h.8 : “.... punishment has three sorta of general preventive effects : it may havea deterrent effect; it may strengthen moral inhibitions (a moralizing effect), and it may stimulate habitual law-abiding conduct".
} 


\begin{abstract}
Berdasarkan hal tersebut diatas, tujuan dan manfaat yang dapat diharapkan dari adanya penelitian tersebut adalah :
a) Hasil penelitian diharapkan dapat memberikan sumbangan kearah pengembangan atau kemajuan dibidang ilmu pengetahuan hukum pada umumnya dan khususnya adalah hukum pidana.

b) Memberikan bahan masukan bagi penelitian yang sejenis berikutnya.

c) Menambah khasanah bahan pustaka pada ilmu hukum Fakultas Hukum Universitas Stikubank (Unisbank) Semarang.

d) Memberikan informasi kepada masyarakat luas mengenai pertimbangan hakim terkait penjatuhan sanksi pidana terhadap pelaku tindak pidana perdagangan orang dalam Putusan Nomor 632 K/ PID. SUS 2016 dan Putusan Nomor 1447 K/ PID. SUS/ 2016, sehingga diharapkan menjadi masyarakat yang melek hukum.

e) Menambah literatur atau bahan - bahan informasi mengenai perbandingan pertimbangan hakim terkait penjatuhan sanksi pidana terhadap pelaku tindak pidana perdagangan orang dalam Putusan Nomor 632 K/ PID. SUS 2016 dan Putusan Nomor 1447K/PID.SUS/ 2016.

\section{Metode Penelitian \\ Tipe Penelitian}

Penelitian ini disusun dengan menggunakan tipe penelitian yuridis normatif yaitu penelitian yang difokuskan untuk mengkaji penerapan kaidah - kaidah atau norma - norma dalam hukum positif $^{11}$.

Yuridis normatif adalah pendekatan yang menggunakan konsepsi legis positivis. Dimana konsep ini memandang hukum identik dengan norma - norma tertulis yang dibuat dan diundangkan oleh lembaga atau pejabat yang berwenang. Konsepsi ini memandang hukum sebagai suatu sistem normatif yang bersifat mandiri, tertutup dan terlepas dari kehidupan masyarakat yang nyata. $^{12}$

Menurut Soerjono Soekanto penelitian yuridis normatif yaitu penelitian hukum yang dilakukan dengan cara meneliti bahan pustaka atau data sekunder sebagai bahan dasar untuk diteliti dengan cara mengadakan penelusuran terhadap peraturan - peraturan dan literatur - literatur yang berkaitan dengan permasalahan yang diteliti $^{13}$

\footnotetext{
${ }^{11}$ Johnny Ibrahim, “Teori dan Metodologi Penelitian Hukum Normatif”, Malang: Bayumedia Publishing, 2006. hlm. 295.

${ }^{12}$ Ronny Hanitijo Soemitro, "Metodologi Penelitian Hukum dan Jurimetri". Jakarta: Ghalia Indonesia. 1988. Hlm. 13-14.

${ }^{13}$ Soerjono Soekanto \& Sri Mamudji,

"Penelitian Hukum Normatif (Suatu Tinjauan Singkat), Jakarta: Rajawali Pers, 2001. Hlm, $13-14$.
} 
Dengan menggunakan metode ini, penelitian diawali dengan mengkaji berbagai peraturan perundang - undangan tentang pemidanaan bagi pelaku tindak pidana perdagangan orang. Serta menghubungkan terkait pertimbangan hakim dalam menjatuhkan pidana terhadap pelaku tindak pidana perdagangan orang. Dengan penelitian ini diharap lebih memperberat penjatuhan sanksi bagi pelaku tindak pidana perdagangan orang.

\section{Spesifikasi Penelitian}

Spesifikasi penelitian yang digunakan adalah penelitian hukum in concreto merupakan suatu penelitian untuk menemukan hukum bagi suatu perkara in concreto merupakan suatu usaha apakah hukumnya yang sesuai untuk diterapkan in concreto guna menyelesaikan suatu perkara tertentu. ${ }^{14}$

Dalam hal ini penelitian hukum in concreto berupaya penyelesaian peristiwa hukum konkrit melalui putusan pengadilan terhadap tindak pidana perdagangan orang, melalui Undang - Undang Pemberantasan Tindak Pidana Perdagangan Orang Nomor $21 \quad$ Tahun 2007 sebagaimana telah diatur dalam ketentuan peraturan perundang -

${ }^{14}$ Ronny Hanitijo Soemitro, "Metodologi Penelitian Hukum dan Jurimetri”. Jakarta: Ghalia Indonesia. 1988. Hlm. 22. undangan, untuk mencari apakah kesesuaian terhadap hukum untuk diterapkan yang terdapat pada putusan pengadilan

\section{Sumber Data}

Sumber data yang digunakan dalam penelitian ini adalah data sekunder yang merupakan keterangan atau fakta - fakta yang diperoleh secara tidak langsung tetapi melalui studi kepustakaan melalui literatur - literatur, pendapat para ahli serta perundang - undangan yang berkaitan dengan penelitian yang dilakukan. ${ }^{15}$

Data sekunder di bidang hukum (dipandang dari sudut kekuatan mengikatnya) dibedakan menjadi :

- Bahan - bahan Hukum Primer $^{16}$

Yaitu bahan - bahan hukum yang mempunyai kekuatan yang mengikat terdiri dari :

- Undang - Undang Dasar Negara Republik Indonesia Tahun 1945;

- Kitab Undang - Undang Hukum Pidana (KUHP);

- Undang - Undang Nomor 21 Tahun $2007 \quad$ Tentang Pemberantasan Tindak Pidana Perdagangan Orang ;

\footnotetext{
${ }^{15}$ Indri Duwi Kiswari, “Ganti Rugi dari Pemrakarsa Terhadap Korban Pencemaran Lingkungan Hidup”, Fakultas Hukum, Universitas Stikubank (UNISBANK) Semarang, 2017. hlm. 42.

${ }^{16}$ Ronny Hanitijo Soemitro, "Metodologi Penelitian Hukum dan Jurimetri”. Jakarta: Ghalia Indonesia. 1988. Hlm. 11.
} 
- Undang - Undang Nomor 39

Tahun 1999 tentang HAM;

- Undang - Undang Nomor 23

Tahun 2002 Tentang Perlindungan

Anak;

- Putusan Mahkamah Agung

Republik Indonesia Nomor 1447

K.PID.SUS/2016;

- Putusan Mahkamah Agung

Republik Indonesia Nomor 632

K/PID.SUS/2016;

\section{- Bahan - bahan Hukum}

Sekunder

Yaitu bahan - bahan hukum yang erat hubungannya dengan bahan hukum primer dan dapat membantu menganalisis dan memahami

bahan hukum primer, ${ }^{17}$ yaitu :

- Buku - buku yang berkaiatan dengan tindak pidana perdagangan orang;

- Literatur - literatur

- Rancangan

peraturan

perundang -undangan;

- Hasil karya ilmiah para sarjana tentang tindak pidana perdagangan orang.

- Bahan - bahan Hukum Tersier Yaitu bahan - bahan yang memberikan informasi tentang bahan hukum primer dan bahan hukum sekunder ${ }^{18}$ misalnya :

- Kamus Besar Bahasa Indonesia;

- Ensiklopedia.

\section{Metode Pengumpulan Data}

Metode pengumpulan data dalam penelitian ini adalah studi kepustakaan, yaitu suatu cara yang dilakukan guna mendapatkan landasan teori berupa pendapat - pendapat atau tulisan tulisan para ahli atau pihak - pihak yang berwenang dan juga untuk memperoleh informasi baik dalam ketentuan formal maupun data melalui naskah resmi yang asli.

\section{Studi kepustakaan dalam penelitin ini dilakukan dengan menelusuri materi - materi yang terkait baik yang berada di dalam buku, peraturan perundang - undangan, maupun dari jurnal ilmiah. $^{19}$}

\section{Metode Penyajian Data}

Metode penyajian data dalam penlitian ini dilakukan dengan cara deskriptif analitis yaitu menjelaskan atau menggambarkan kenyataan kenyataan yang terjadi pada objek penelitian secara tepat dan jelas untuk memperoleh kejelasan masalah yang timbul.

Dalam penelitian ini menjelaskan dan kemudian data disajikan dalam bentuk uraian atau berupa penjelasan atau jabaran atas permasalahan mengenai pertimbangan hakim terkait

\footnotetext{
${ }^{19}$ Wiwit Sholechah, "Analisis Yuridis Atas Pemberatan Pidana Perdagangan Orang.............. Op.Cit. hlm. 38.
}

${ }^{17}$ Ronny Hanitijo Soemitro, "Metodologi Penelitian Hukum...... Op.Cit. Hlm. 12

${ }^{18}$ Ronny, Ibid. 
penjatuhan pidana terhadap pelaku tindak pidana perdagangan orang.

\section{Metode Analisis Data}

Dalam penelitian ini digunakan analisis deskriptif kualitatif untuk menggambarkan mengenai peraturan perundang undangan yang dapat menjaring pelaku tindak pidana perdagangan orang dan pertimbangan hakim terkait penjatuhan pidana terhadap pelaku tindak pidana perdagangan orang dengan mempelajari buku buku atau literatur - literatur yang relevan dengan pokok permasalahan agar didapat suatu kesimpulan kemudian disusun secara sistematis dalam bentuk laporan penelitian.

Menurut Rebecca Surtees dan Martha Wijaya, tindak pidana perdagangan orang adalah sindikat kriminal yaitu merupakan perkumpulan dari sejumlah orang yang terbentuk untuk melakukan aktivtas kriminal. Dari pengertian di atas sindikat kriminal yaitu perbuatan yang dilakukan oleh lebih dari satu orang yang telah melakukan tindak pidana dalam pelasaksanaannya. ${ }^{20}$

\section{HASIL PENELITIAN DAN ANALISIS}

\section{Dasar Pertimbangan Hakim Dalam Penjatuhan Sanksi Pidana}

\footnotetext{
${ }^{20}$ Farhana, "Aspek Hukum Perdagangan Orang di Indonesia”, Jakarta, Sinar Grafika, 2010. Hlm, 20.
}

\section{Terhadap Pelaku Tindak Pidana Perdagangan Orang}

Mahkamah Agung RI sebagai badan tertinggi pelaksana kekuasaan kehakiman yang membawahi empat badan peradilan dibawahnya telah menentukan bahwa putusan hakim harus mempertimbangkan segala aspek yang bersifat yuridis, filosofis, dan sosiologis. ${ }^{21}$

Aspek yuridis merupakan aspek pertama dan utama dengan berpatokan pada undang - undang yang berlaku. Hakim sebagai aplikator undang - undang harus memahami dan dengan mencari undang - undang yang berkaitan dengan perkara yang sedang dihadapi. Hakim harus menilai apakah undang _ undang itu adil, ada kemanfaatannya atau memberikan kepastian hukum jika ditegakkan, sebab salah satu tujuan hukum itu unsurnya adalah menciptakan keadilan.

Aspek filosofis merupakan aspek yang rintikan pada kebenaran dan keadilan, sedangkan aspek sosiologis penerapannya sangat memerlukan pengalaman dan pengetahuan yang luas serta kebijaksanaan yang mampu mengikuti nilai - nilai hukum dalam masyarakat yang

\footnotetext{
${ }^{21}$ Mahkamah Agung RI, Pedoman Perilaku Hakim (Code of Conduct), Kode Etik Hakim dan Makalah berkaitan, Pusdiklat MA RI, Jakarta, 2006,. Hlm. 2.
} 
terabaikan. Jelas penerapannya sangat sulit karena tidak mengikuti asas legalitas dan tidak terikat pada sistem. Pencantuman ketiga unsur tersebut tidak lain agar putusan dianggap adil dan diterima masyarakat. $^{22}$

Tindak pidana perdagangan orang merupakan masalah yang sangat serius dan sudah menjadi isu bahasan dunia Internasional, dan Undang - Undang Nomor 21 Tahun 2007 Tentang Tindak Pidana Perdagangan Orang merupakan salah satu sikap pemerintah Indonesia dalam menangani masalah yang sangat serius ini, dengan adanya payung hukum tersebut diharapkan melindungi para tenaga kerja Indonesia yang bekerja di luar negeri agar terjamin keselamatan, kehidupan maupun hak - hak asasinya.

\section{Dasar Pertimbangan Hakim Terhadap Putusan Nomor 632K/PID.SUS 2016}

Dalam Putusan Pidana Perkara Nomor 632K/PID.SUS/2016 memutus bahwa Terdakwa Yuliana Jati alias Ibu Yuli binti Yohanes Anamela yang pekerjaannya adalah wiraswasta (koordinator PT Graha Indrawahana Perksa) dengan Direktur Utama PT Graha Indrawahana Perkasa di Semarang, Sutadie Lie dan Kepala Cabang
Budiyanto PA di Kupang telah melakukan tindak pidana "Turut serta merekrut tenaga kerja Indonesia yang masih dibawah umur”.

\section{Posisi Kasus Putusan Nomor 632} K/ PID. SUS 2016

Bahwa Terdakwa Yuliana Jati alias Ibu Yuli binti Yohanes Anamela bersama - sama dengan Sutadie Lie bin Lie Tjin Goong, Budiyanto PA bin Yosep PA (Terdakwa dalam dakwaan terpisah) pada hari hari yang sudah tidak dapat ditentukan lagi secara pasti antara bulan Mei tahun 2014 sampai dengan hari Jum'at tanggal 27 September 2017 atau pada suatu waktu tertentu dalam bulan Mei sampai dengan bulan September tahun 2014, di beberapa tempat tertentu yaitu : di Bilu Wawi, Umbu Riri, Katikutana, Kabupaten Sumba Tengah, Jalan Bhakti Warga Nomor 10 Kelurahan Fatulli Kecamatan Oebobo, Kota Kupang, dan di Jalan Puri Anjasmoro Blok A.2 Nomor 29 Kecamatan Semarang Barat, Kota Semarang.

\section{Analisis Pertimbangan Hakim Terhadap Putusan Nomor 632K/PID.SUS 2016}

Berikut adalah hal - hal yang memberatkan terdakwa :

1. Bahwa Terdakwa melakukan tindak pidana "Turut serta

\footnotetext{
${ }^{22}$ Mahkamah Agung RI. Ibid.
} 
merekrut tenaga kerja Indonesia yang masih di bawah umur".

2. Bahwa Terdakwa selaku koordinator yang diberikan tugas merekrut calon tenaga kerja di wilayah Sumba Tengah telah mengetahui persyaratan yang harus dipenuhi untuk merekrut tenaga kerja.

3. Bahwa Terdakwa juga merekrut tenaga kerja (CTKI) yang masih di bawah umur dan bahkan terdakwa mengurus kelengkapan dokumen dengan cara memalsukan tanggal dan tahun kelahiran CTKI.

4. Perbuatan Terdakwa yang memalsukan dokumen telah disampaikan kepada Direktur Utama PT Graha Indrawahana Perkasa di Semarang, Sutadie Lie dan Kepala Cabang Budiyanto PA di Kupang dan telah disetujui oleh Direktur Utama dengan tujuan agar para CTKI dapat dikirim ke luar negeri.

5. Bahwa perbuatan Terdakwa yang merekrut CTKI dari awal sudah ada kerja sama antara Terdakwa selaku koordinator, Kepala Cabang dan Direktur Utama.

6. Bahwa Terdakwa dengan harapan mendapatkan keuntungan yang lebih besar apabila dapat merekrut banyak CTKI.

Hal-hal yang meringankan terdakwa adalah :

1. Terdakwa telah mengkaui perbuatannya dan menyesal.
2. Terdakwa masih usia produktif sehingga diharapakan dapat untuk merubah atau memperbaiki kesalahannya.

\section{Dasar Pertimbangan Hakim} Terhadap Putusan Nomor 1447 K/ PID. SUS/ 2016

Dalam Putusan Pidana

Perkara Nomor 1447 K/PID.SUS/ 2016 memutus bahwa Terdakwa Aziz alias Azizah alias Cizza yang pekerjaannya adalah tidak ada (pengangguran) di Makasar terbukti secara sah dan meyakinkan bersalah telah melakukan tindak pidana “Perdagangan Orang”.

\section{Posisi Kasus Putusan Nomor 1447K/ PID.SUS/2016}

Bahwa ia Terdakwa AZIZ alias AZIZAH alias CIZZA pada hari Sabtu tanggal 13 Juni 2015 sekitar pukul 20.00 WITA atau setidak - tidaknya masih dalam tahun 2015 bertempat di jalan Pelita Raya Kota Makasar (D"Maleo Hotel) atau setidak tidaknya pada suatu tempat lain yang masih termasuk dalam daerah hukum Pengadilan Negeri Makasar yang berwenang untuk memeriksa, dan mengadili, melakukan perekrutan pengangkutan, penampungan, pengiriman, pemindahan atau penerimaan seseorang dengan ancaman kekerasan, penggunaan kekerasan, penculikan, penyekapan, pemalsuan, penipuan, 
penyalahgunaan kekuasaan atau posisi rentan, penjeratan hutang atau memberi bayaran atau manfaat alaupun memperoleh persetujuan dari orang yang memegang kendali atas orang lain, untuk tujuan mengeksploitasi orang tersebut di Wilayah Republik Indonesia, yang dilakukan dengan cara cara sebagai berikut :

Pada waktu dan tempat tersebut di atas berawal saat Petugas dari Kepolisian Daerah Makasar (POLDA) yakni saat saksi Brigpol Taswin Zardi melakukan penyamaran bernama ARI sebagai pelanggan wanita dan memesan perempuan melalui Terdakwa Aziz alias Azizah alias Cizza dengan cara melalui media sosial via BBM dan saat transaksi berlangsung Terdakwa Aziz alias Azizah alias Cizza mengirimkan 4 (empat) buah foto wanita melalui via BBM sebagai pilihan dan adapun tarif wanita tersebut yang disuruh melayani pelanggan sebesar Rp1.500.000,00 (satu juta lima ratus ribu rupiah) setelah itu wanita - wanita disuruh Terdakwa Aziz alias Azizah alias Cizza ke Hotel D’Maleo kamar 707 untuk melayani pelanggan tersebut (hubungan intim layaknya suami isteri).

Bahwa wanita - wanita yang datang ke Hotel Maleo adalah saksi Mirawati alias Mira, saksi Mikawati alias Mika, Andi Alya alias Aca Rasya alias Acha. Setelah itu saksi Brigpol Taswin Zardi yang mengaku bernama Ari memilih satu wanita tersebut yakni Mikawati sedang 3 orang langsung ke lobby hotel melalui lift dan saat hendak meninggalkan hotel Tim Polda Sulsel untuk pemeriksaan dan juga mengamankan saksi Mikawati. Setelah dilakukan pemeriksaan wanita - wanita tersebut diperoleh informasi bahwa yang mencarikan pelanggan adalah Terdakwa Aziz alias Azizah alias Cizza yang tinggal di Jalan Raya Pendidikan Blok G1 Nomor 1 Makasar namun saat Tim dari Direktorat Reserse Kriminal Polda Sulsel mendatangi alamat tersebut namun Terdakwa Aziz alias Azizah alias Cizza tidak ada ditempat selanjutnya dilakukan pencarian dan Terdakwa Aziz alias Azizah alias Cizza ditemukan di Bulukumba lalu diamankan dan dibawa di Polda Sulsel. Terdakwa Aziz alias Azizah alias Cizza mendapatkan keuntungan sebesar Rp500.000,00 (lima ratus ribu rupiah) dari setiap transaksi penjualan wanita kepada setiap pelanggan. Tedakwa Aziz alias Azizah alias Cizza berprofes sebagai mucikari sudah berlangsung sejak tahun 2012 sampai ditangkap oleh penyidik Polda Sulsel. Tim dari Direktorat Reserse Kriminal Umum Polda Sulsel mengetahui bahwa 
Terdakwa Aziz alias Azizah alias Cizza sering menjual wanita ke lelaki hidung belang berdasarkan informasi dari masyarakat yang menyampaikan bahwa transaksi prostitusi yang dilakukan Terdakwa Aziz alias Azizah alias Cizza menggunakan media sosial online BBM sehingga dari informasi tersebut dibuatkan Surat Perintah Tugas Nomor Polisi : Sp.Gas/ 615/ VI/2015/ Ditreskrim tangal 10 Juni 2015.

\section{Analisis Pertimbangan Hakim Terhadap Perkara Nomor 1447 K/PID. SUS/ 2016}

Hal - hal yang memberatkan terdakwa adalah :

1. Bahwa benar Terdakwa Aziz alias Azizah alias Cizza terbukti secara sah dan meyakinkan bersalah melakukan tindak pidana "Perdagangan Orang".

2. Bahwa Terdakwa Aziz alias Azizah alias Cizza benar melakukan perekrutan Saksi Mirawati alias Mira, saksi Mikawati alias Mika, Andi

3. Alya alias Alya dan Aca Rasya alias Acha untuk melayani pelanggan dengan tarif sebesar Rp1.500.000,00 (satu juta lima ratus ribu rupiah) di Hotel D’Maleo kamar 707.

4. Bahwa perbuatan yang dilakukan oleh Terdakwa sangat tidak terpuji dan melanggar norma maupun moral agama dan etika serta merusak generasi muda.
5. Bahwa transaksi prostitusi yang dilakukan oleh Terdakwa Aziz alias Azizah alias Cizza menggunakan media sosial online BBM.

Hal yang meringankan yaitu terdakwa telah mengakui perbuatannya dan menyesal.

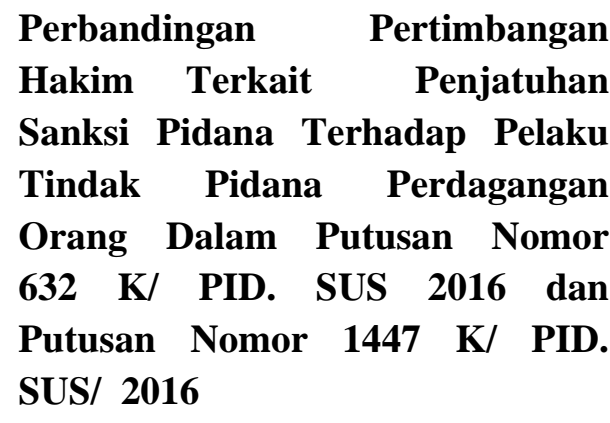

1. Pertimbangan yang berifat yuridis

Merupakan pertimbangan hakim yang didasarkan pada fakta - fakta yuridis yang terungkap di dalam persidangan oleh undang undang. Dakwaan jaksa penuntut umum merupakan salah satu dari pertimbangan yuridis. Selain itu dakwaan digunakan sebagai bahan pertimbangan pengadilan, perumusan dakwaan dalam putusan nomor 632K/PID.SUS/2016 yaitu dalam Pasal 6 juncto Pasal 10 juncto Pasal 11 Undang - Undang Nomor 21 Tahun 2007 tentang Tindak Pidana Perdagangan Orang.

Dengan pidana penjara selama 2 (dua) tahun dan denda sebesar Rp1.000.000.000,00 (satu miliar rupiah).

Dalam putusan nomor 1447K/PID.SUS/2016 dakwaan berupa pelanggaran Pasal 12 
Undang - Undang Nomor 21 Tahun 2007 tentang Tindak Pidana Perdagangan Orang. Dengan pidana penjara 3 (tiga) tahun dan denda Rp120.000.000,00 (seratus dua puluh juta rupiah).

\section{Pertimbangan yang berifat filosofis}

Penjatuhan pidana penjara terhadap Terdakwa Yuliana Jati alias Ibu Yuli binti Yohanes Anamela tersebut sama sekali tidak memperhatikan "fakta yang ditemukan di persidangan dan rasa keadilan masyarakat" sebagai akibat dari perbuatan yang dilakukan oleh terdakwa.

Bahwa akibat dari perbuatan terdakwa secara sosiologis berpengaruh terhadap orang tua dan para keluarga korban serta masyarakat sekitar yang tinggal di lingkungan korban. Berdasarkan fakta yang ditemukan di persidangan, dimana korban yang masih di bawah umur (yang notabene secara psikis belum siap untuk bekerja di luar negeri) telah diperlakukan dan dipekerjakan tidak sesuai dengan usia mereka, yang berakibat para korbannya mengalami penderitaan fisik, psikis (kejiwaan/ atau trauma).

Sedangkan dalam penjatuhan pidana penjara terhadap Terdakwa Aziz alias Azizah alias Cizza selama 3 (tiga) tahun dan denda Rp120.000.000,00 (seratus dua puluh juta rupiah) tersebut tidak mengandung efek jera dan perbuatan yang dilakukan Terdakwa sangat tidak terpuji dan melanggar moral agama dan etika serta merusak generasi muda. Sehingga perbuatan terdakwa berpotensi akan diulangi dan menciptakan kehancuran bagi generasi muda masa depan bangsa.

3. Pertimbangan yang bersifat sosiologis

Merupakan langkah - langkah hakim dalam mengidentifikasi, mengkualifikasi dan terakhir menyimpulkan sehingga melahirkan putusan yang sudah sesuai dengan langkah - langkah dalam penalaran hukum dan tampak jelas pada hasil putusannya, hal ini didasari dari latar belakang terdakwa maupun motif yang digunakan.

Berikut adalah hal - hal yang memberatkan terdakwa dalam putusan nomor 632K/PID.SUS/2016 :

1. Bahwa Terdakwa melakukan tindak pidana "Turut serta merekrut tenaga kerja Indonesia yang masih di bawah umur".

2. Bahwa Terdakwa selaku koordinator yang diberikan tugas merekrut calon tenaga kerja di wilayah Sumba Tengah telah mengetahui persyaratan yang harus dipenuhi untuk merekrut tenaga kerja.

3. Bahwa Terdakwa juga merekrut tenaga kerja (CTKI) yang masih di bawah umur dan bahkan terdakwa mengurus 
kelengkapan dokumen dengan cara memalsukan tanggal dan tahun kelahiran CTKI.

Dan hal yang meringankan adalah :

- Terdakwa telah mengkaui perbuatannya dan menyesal.

- Terdakwa masih usia produktif sehingga diharapakan dapat untuk merubah atau memperbaiki kesalahannya.

Sedangkan dalam putusan nomor 1447K/PID.SUS/2016, berikut adalah hal - hal yang memberatkan terdakwa :

1. Bahwa benar Terdakwa Aziz alias Azizah alias Cizza terbukti secara sah dan meyakinkan bersalah melakukan tindak pidana "Perdagangan Orang”.

2. Bahwa Terdakwa Aziz alias Azizah alias Cizza benar melakukan perekrutan Saksi Mirawati alias Mira, saksi Mikawati alias Mika, Andi

3. Alya alias Alya dan Aca Rasya alias Acha untuk melayani pelanggan dengan tarif sebesar Rp1.500.000,00 (satu juta lima ratus ribu rupiah) di Hotel D’Maleo kamar 707.

4. Bahwa perbuatan yang dilakukan oleh Terdakwa sangat tidak terpuji dan melanggar norma maupun moral agama dan etika serta merusak generasi muda.

Hal yang meringankan yaitu
terdakwa telah mengakui
perbuatannya dan menyesal.

\section{SIMPULAN DAN SARAN}

Dasar pertimbangan hakim dalam penjatuhan sanksi pidana terhadap pelaku tindak pidana pedagangan orang meliputi 3 aspek yaitu :

1. Aspek yuridis berupa dasar tuntutan dari jaksa penuntut umum, dalam putusan nomor 632K/PID.SUS/2016, yaitu telah melanggar pasal 6 juncto pasal 10 juncto pasal 11 Undang - Undang Nomor 21 Tahun 2007. Aspek yuridis dalam putusan Nomor 1447K/PID/SUS/2016 yaitu pasal 12 Undang - Undang Nomor 21 Tahun 2007.

2. Aspek filosofis merupakan aspek kebenaran dan keadilan. Dalam putusan nomor 632K/PID.SUS/2016 yaitu putusan pidana penjara 2 tahun dan denda 1 Milyar, sedangkan dalam putusan nomor 1447K/PID.SUS/2016 yaitu pidana penjara 3 tahun dan denda 120 Juta.

3. Aspek sosiologis mengandung nilai - nilai hukum kemasyarakatan, dalam putusan nomor 632K/PID.SUS/2016 terdakwa Ibu Yuli dalam kegiatan perdagangan orang dengan merekrut tenaga kerja yang 
dibawah umur, sedangkan dalam putusan nomor 1447K/PID.SUS/2016 aspek sosiologisnya yaitu perbuatan terdakwa Cizza yang dinilai telah melanggar norma, etika dan agama. Dimana akibat dari perbuatan terdakwa tersebut dapat menciptakan kehancuran bagi generasi bangsa.

\section{Perbandingan}

pemidanaan

Putusan Mahkaman Agung Nomor 632K/PID.SUS/2016 dan Putusan Nomor 1447K/ PID.SUS/2016

1. Aspek yuridis

- Putusan nomor 632K/PID.SUS/2016 yaitu telah melakukan kegiatan perekrutan tenaga kerja di bawah umur dan akan memperkejakannya di luar negeri dengan cara pemalsuan dokumen.

- Putusan nomor 1447K/PID/SUS/2016 yaitu terdakwa Cizza telah melakukan kegiatan perdagangan orang dengan memfasilitasi, menyuruh, maupun memperkejakan korban.

2. Aspek filosofis

\section{- Putusan}

Nomor

632K/PID.SUS/2016 yaitu terdakwa terlibat dalam kegiatan korporasi perdagangan orang, sehingga pidana denda yang dijatuhkan lebih tinggi sesuai dengan golongan penjatuhan pidana penjara pidana 2 tahun, karena adanya kterlibatan perusahaa atau korporasi.

- Putusan

Nomor

1447K/PID/SUS/2016, penjatuhan pidana dan denda tidak sebanyak terdakwa Ibu Yuli, karena kegiatan perdaganga orang yang dilakukan oleh terdakwa masih menggunakan metode atau motif yang lama, yaitu menawarkan perempuan melalui media sosial.

3. Aspek sosiologis

- Putusan Nomor 632K/PID.SUS/2016, hal yang memberatkan terdakwa yaitu perekrutan calon tenaga kerja yang masih dibawah umur dan memalsukan dokumen kelengkapannya, dan yang meringankan terdakwa yaitu usia terdakwa yang masih produktif yang diharapkan merubah dan memperbaiki kesalahnnya.

- Putusan Nomor 1447K/PID/SUS/2016, hal yang memberatkan terdakwa yaitu melanggar norma, nilai masyarakat, moral, etika, agama. Sehingga berpotensi akan diulangi dan menciptakan kehancuran bagi genarasi muda bangsa. Sedangkan hal yang meringankan yaitu terdakwa mengakui perbuatannya dan menyesal.

\section{Saran}

- Seharusnya hakim perlu mempertimbangkan ulang sanksi pidana, terkait perbuatan tindak pidana perdagangan orang yang dilakukan terdakwa, sehingga berpotensi untuk diulangi kembali dan merusak generasi bangsa. 
- Hendaknya hakim juga memperhatikan pemulihan korban, karena dalam perundang undangan tersebut belum mencerminkan kepentingan dan perlindungan dari wanita. Akibat dari perbuatan pelaku tindak pidana perdagangan orang

\section{DAFTAR PUSTAKA}

\section{BUKU}

Arief, Nawawi Barda, 2010, Masalah Penegakan Hukum dan Kebijakan Hukum Pidana dalam Penanggulangan Kejahatan, Kencana Prenada Media Group, Jakarta. 2011, Tujuan dan Pedoman Pemidanaan (Perspektif Pembaharuan \& Perbandingan Hukum Pidana), Pustaka Magister, Jakarta.

Manan, Bagir, 2006, Perkembangan

Pemikiran dan Pengaturan

Hak Asasi Manusia di Indonesia, Alumni, Bandung.

Candra, Muzaffar dkk, 2007, Human's wrong: Rekor Buruk DominasiBarat atas HAM, Pilar Media, Yogyakarta.

Farhana, 2010, Aspek Hukum Perdagangan Orang diIndonesia, Sinar Grafika, Jakarta.

Henny Nuraeny, 2016, Tindak Pidana Perdagangan Orang berdampak secara emosional jiwa, fisik, psikis dan trauma yang mendalam bagi korban.

Perlunya pelatihan dan pendidikan bagi hakim tentang perlindungan korban atau typology.

Dalam Perspektif Hak Asasi Manusia Rajawali Pers, Jakarta. Johnny Ibrahim, 2006, Teori dan Metodologi Penelitian Hukum Normatif, Bayumedia Publishing, Malang.

Ronny Hanitijo Soemitro, 1988. Metodologi Penelitian

Hukumdan Jurimetri. Ghalia Indonesia, Jakarta.

Yahya Harahap, sebagaimana dikutip M. Syamsudin, 2012, Konstruksi Baru Budaya Hukum Hakim Berbasis Hukum Progresif, Kencana, Jakarta.

\section{SKRIPSI}

Andi Atika, “Tinjauan Yuridis Terhadap Tindak Pidana Perdagangan Orang di Kota Makassar (Studi Kasus Putusan No. 597/Pid.B/2013/PN.MKS)”, Fakultas Hukum, Universitas Hasanuddin Makassar, 2015.

Dwi Maryana Puspita, “Analisis Hukum Pidana Terhadap Putusan Hakim Dalam Perkara Tindak Pidana Penipuan Secara Berlanjut (Delictum Continuatum)”, $\quad$ Fakultas 
Hukum, Universitas Stikubank (UNISBANK) Semarang, 2010. Wiwit Sholechah, "Analisis Yuridis Atas Pemberatan
Pidana
Perdagangan

(Trafficking)", Hukum, Universitas

Semarang, 2011.
Orang

Fakultas

Negeri 